\title{
A Lean Agile Resilient Green Implementation and Technology Utilization: A New Vision in Technology Adoption
}

\author{
Muhammad Zeeshan Rafique ${ }^{1 \mathrm{a}}$, Hamid Iftikhar Qureshi ${ }^{1 \mathrm{~b}}$, Muhammad Umar Malkana ${ }^{1 \mathrm{c}}$, \\ Syed Mustafa Haider ${ }^{1 d}$, Muhammad Atif ${ }^{1 e}$
}

RECEIVED ON 04.02.2019, ACCEPTED ON 03.05.2019

\begin{abstract}
Lean Manufacturing is always important for process improvement in manufacturing industries especially in deem of adoption but the implementation of simple lean is not enough to attain required results. A recent trend has been observed regarding the implementation of strategies like Lean, Agile, Resilient and Green (LARG) in combination to attain fruitful results. However, this combination carries a complication regarding its understanding and implementation and a gap observed regarding the availability of literature study that can cope all these strategies on one platform for understanding and can suggest a proper implementation method. It has been observed that there are some new models that are utilizing electronic configurations to provide powerful platform for process improvements. Utilization of LARG as tool or technique in combination of technologies can be very effective for process improvements. Therefore, this current work emphasis on the combining of LARG along with wireless technologies for obtaining a sustainable improvement in manufacturing sector, which seems unavailable. Based on this ideology, the aim of this research is to conduct a systematic literature study that reviews the previously available LARG research with the objectives to first study the LARG combination for understanding and to develop the interrelation between LARG and previous available technologies for its successful implementation. The literature study results that the LARG combination has many benefits like helpful to attain elimination of non-value activities (lean), responsive to the changing demands of customers as per increasing volatile market (agile), responsive to the unexpected disruptions (resilient) and to adopt environmental protection (green) but typically lacks its utilization with modern technologies (Like RFID) that will be helpful to attain successful implementation. The contribution of this study is the next generation in LARG implementation to emphasis more on the combining of LARG implemetation with utilization of modern technologies.
\end{abstract}

Keywords: Technology Adoption, Lean Manufacturing; Agile Manufacturing, Resilient Manufacturing Green Manufacturing, Lean, Agile, Resilient and Green Combination.

\section{INTRODUCTION}

$\mathrm{W}$

ith the continuously increasing competition, Industries are transitioning toward the modern manufacturing techniques to compete in the market. Technology innovation has brought variety in products [1], thus transition toward the modern manufacturing techniques has now become vital for the survival of company in the global competition [2]. Each industry

\footnotetext{
${ }^{1}$ Department of Mechanical Engineering, The University of Lahore, Lahore, Pakistan.

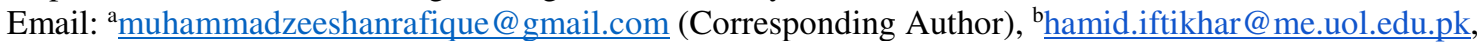
cumalkana41@gmail.com, ${ }^{\mathrm{d}}$ mustafahaider786@gmail.com, ${ }^{\mathrm{e}}$ muhammad.atif1@me.uol.edu.pk
}

This is an open access article published by Mehran University of Engineering and Technology, Jamshoro, under CC BY 4.0 International License. 
tries to implement the technique depending upon its requirement out of which Lean manufacturing technique is the most common one. Lean manufacturing technique is the basic need of every industry as it proceeds toward the reduction of wastes (transport, inventory, waiting etc.) and a consistent assessment is required for its sustainability. With the changing environment, mass production is becoming obsolete as the customer look for modern and innovating products. This demands flexibility in the manufacturing systems [3] and agility from the past few decades has been adopted to harbor flexible adaptation to the demands. Agile manufacturing demands operations to run in collaboration of different departments. Agility focuses on time management while flexibility aims at capabilities measurement [4]. A call of daily meeting is decided to discuss what is done, what is being done and what to do next. Resilience management has had been a need to cut down these effects for a long time while maintaining the flow of work [5]. Across all of these fields the concept the context of the term resilience may change, is closely related with the capability and ability of an element to return to a stable state after a disruption [6].

A sustainable manufacturing system also calls for environmental friendly processes [7] and green manufacturing implementation is necessarily becoming company's priority in selection of supplier input. Green manufacturing has captured the minds of research scientists in this world of increasing global warming and hazardous gases [8]. Efforts to reduce the consumption of energy and resources in manufacturing processes are considered. Many modern organizations are striving to sustain their market share, this requires their awareness on the adaptation of different holistic strategies in order to survive in this era of market competition [9]. Now organizations are realizing that simply implementation of lean manufacturing or agile does not full fill the requirements of their future challenges and it would require the combination of many useful techniques such as LARG along with the wireless technology so this framework may result in many advantages in implementation. Organizations are recognizing LARG technique as a tool for achieving sustainable competitive advantages [10]. The concept of LARG is to synchronized combination of lean, agile, resilient and green in a most suitable way for organizational benefits. However, the synchronized management of many different techniques is not an easy task as these techniques have dissimilarities in their workings [11], in contrast to this point of view few researchers have opinions that these four techniques do have overlapping in few aspects [12-13].

To utilize the meaningful combination of these techniques many efforts have been made by researchers and these prevail knowledge and understanding of LARG concept [10, 14-15], furthermore it also helped to fill the knowledge gap required to find those potential area where the organizations can earn more profit [16-18] and also makes convenient for them to decide which strategy they should implement in the continually changing environment. It has been observed that there are some new models which are utilizing electronic configurations to provide powerful platform for process improvements [19-23]. Therefore, utilizing LARG applications as tools or techniques in combination of technologies can be very effective for process improvements. Therefore, this current work emphasis on the combining of LARG along with wireless technologies for obtaining a sustainable improvement in manufacturing sector that seems unavailable. Keeping these aspects in view, a need of literature review study seems required that can elaborate about the LARG implementation and affected performances with a confirmation of requirement of technology combined LARG to meet the needs of today's changing globe. In order to confirm this task, the authors of this research study have planned to conduct a literature review study with the objectives as follows:

(i) To identify the previously available research about LARG combinational implementations and any compromises in that.

(ii) To identify the interrelation of LARG with wireless technologies.

In order to attain these objectives, the remainder of paper is structured as follows. Section 2 explains about the research methodology that has been adopted to perform this systematic literature review. Section 3 elaborates the results and discussion inclusion of detailed study of LARG Implementation and 
technology utilization in LARG. In last, Section 4 concludes the article with the explanation of managerial implications, limitations and future recommendation.

\section{RESEARCH METHODS}

This study aims to review about lean, agile, resilient and green paradigms based on exploring the previous literature available as previously done [19,21]. Therefore, some research questions need to discuss in order to implement rigorous and extensive research methodology in terms of research objectives as previously discussed in introduction section. A research study has investigated based on the literature available in order to implement a combined LARG paradigm. In start, to study the background the first question is: What are the available lean, green, agile and resilient paradigms? After a detailed search and selection of the literature, the implementation of all paradigms reviewed and contribution of each paradigm considered in the present methodology. The implementation of LARG ideology needs to be studied in view of their contributions, gaps and methodologies, which helped to raise the question considering first objective as mentioned in introduction that is: What are the contributions and originality of LARG implementations available? By providing the available details about the previously available LARG implementation, there is still a need to investigate whether the LARG implementation is utilizing modern technologies and to generate its interrelation will modern technologies which is objective 3 of introduction section and leads to question that is: Is there is any researches about the interrelation between LARG implementation with the help of technology advancements? In view of the research questions that arise in the implementation and review of literature, as mentioned in Fig. 1, the authors were able to approach to the objectives and requirements of this current study. Rafique et. al. [19] clearly mentioned the methodology regime into two criteria: search criteria and selection criteria. In order to perform this search and selection of required papers that will be helpful for the authors in their systematic literature review, the authors have designed a protocol as mentioned in Fig. 2 which has already been utilized by the previous researchers like, Rafique et al. [19], Jadhav et al. [24] and Kitchenham and Brereton [25] in their research study.

\subsection{Search Criteria:}

Since, this research leads to the study of lean, agile, resilient and green combinational effect. So, all of these paradigms when implement separately or combined move the lean implementation towards sustainability. Therefore, a systematic literature review has to be conducted by using these electronic databases recommended by top researchers of this area [19-20,22-23,26-27]. Large numbers of papers of credible high impact factor journals (Science direct, Springer, Emerald Insight, Elsevier, Taylor \& Francis online and many others) searched which contain one of the above-mentioned paradigms or a combination of these paradigms implemented. Basic source of data used for this paper is the information collected from the previous papers in the context of lean, green, agile, resilient, LARG implementation and wireless technology induction either separately or in combined form.

\subsection{Selection Criteria:}

After composing a search criterion for the LARG paradigm, a selection-based design is important to organize the reviewed articles according to the requirements of the research area and the objectives of this study. Selection criteria is the stage in sorting of articles followed by search criteria. Selection criteria takes into account the selection of required articles for the implementation of LARG paradigms in the manufacturing industry. In these selection criteria, papers scrutinized according to the contribution of paradigms, methodology and LARG implementation area. Further, the focus of this research article is to explain the LARG implementation and contribution of each paradigm in the development of the conceptual framework. The articles selected with an objective of LARG implementation studying manufacturing industrial area. Therefore, different articles have been very helpful in achieving the main aim of this study. Scrutiny of articles has done in way of fulfilling the gap in the literature provided in this paper and explicating the previous literature focusing on this aim. According to Morash [28], SCM strategies and 
paradigms should be applied suitably to the supply chain management practices. Hence, for selection of articles based on their contribution, a literature review is very important.

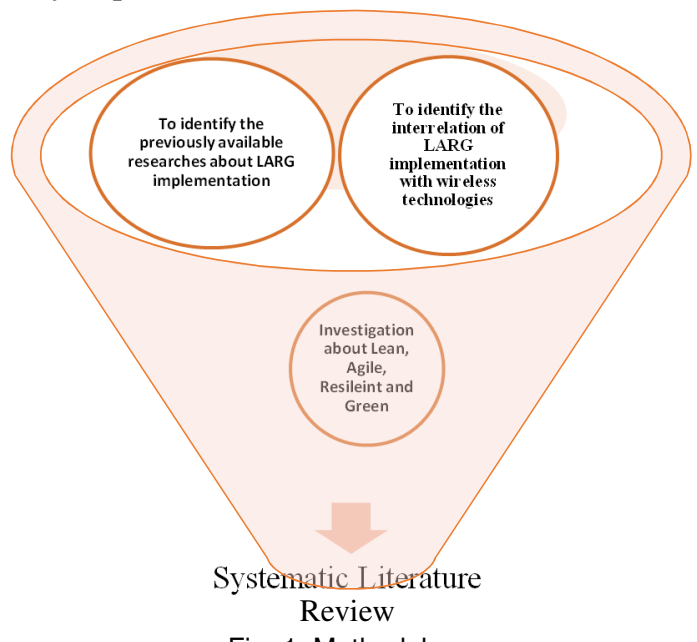

\section{RESULTS and DISCUSSION}

\subsection{A State of Art Literature Review on LARG Implementation}

The competition in the market has forced the companies towards a more competitive supply chain management and the survival for a company has become necessary to be exposed to new technologies and quality management [29]. The organizations are aware of the strategic ingredients to sustain and remain competitive in the growing market [9]. LARG paradigms are found to be the leading paradigms to survive in the current global marketplace. LARG management is about how lean, green, agile and resilient can work together simultaneously to achieve sustainability.

Fig. 1: Methodology

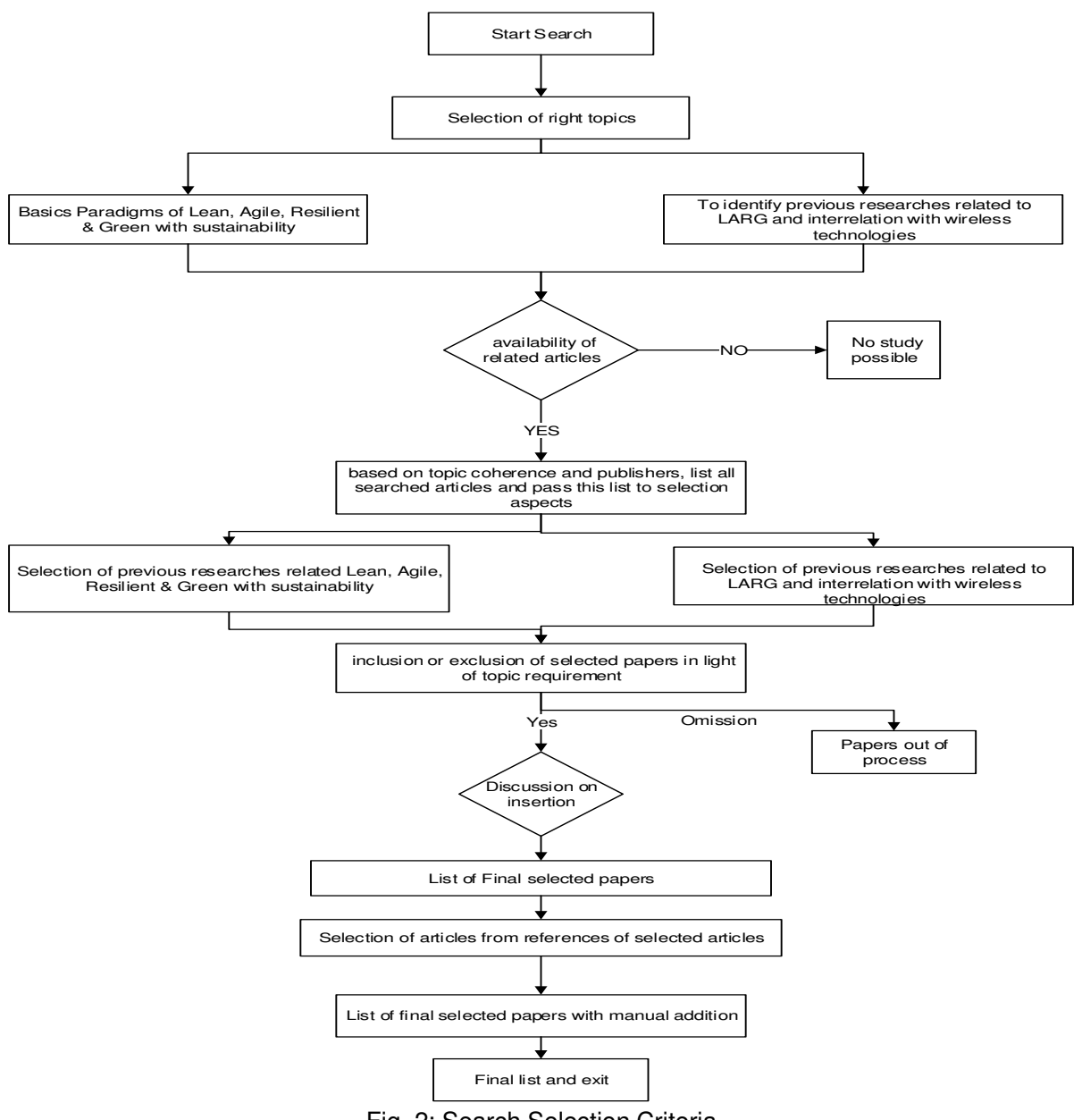

Fig. 2: Search Selection Criteria 
But, it is a very difficult task to manage each paradigm to work in a synchronized manner because of their different way of action [11]. The challenges to respond to the unexpected disruptions (resilient), be responsive to the changing demands of customers in increasing volatile market (agile), environmental protection techniques and restrictions (green) and eliminating the non-value activities and cost and quality management (lean), have attracted company's attention towards the global competition [30]. In short, LARG practices aim to enhance supply chain management efficiency, streamlines and sustainability [10]. A large number of articles shown not only the LARG implementation drivers [14-15], but also provide successful operational performance and three aspects of sustainability (social, economic and environmental) performance [16-18].

Previously, there has been major focus on individual paradigms or combined paradigms. Mittal et al. [31] has presented 10 enablers on LGAM (Lean-GreenAgile Manufacturing) for strategic fortification in view of sustainable performance. Similarly, Verrier et al. [32] provides lean indicators, green indicators and green intensions indicators in a framework to provide strategic solutions for firms to cope their lean and green performance. In achieving the sustainability by the combined action of these paradigms, environmental performance measures have to be kept in mind to ensure global expedition towards environmental protection. Yang et al. [33] details environmental management implementation with the environmental performance measures. Environmental protection is a key aspect of sustainability besides economic and social performance. Involvement of employees at all levels in an organization have been seen an improvement in environmental performance [34]. Economic performance of the latest technologies in various sectors in different countries highlight manufacturing firms contribution to their country is GDP. Goyal and Agrawal [35] has presented a framework showing different managerial and technical practices for practitioners who are inclined to the economic performance of their firms or their nation. A detailed emphasis on socio-economic and environmental issues is presented in [36] focusing on health, pollution and life issues exposed to industrial emissions. A literature on LARG practices and implementation of paradigms is explained in the Table 1.

\subsection{Utilization of Technology in LARG Implementation}

In view of the modern technologies and pressures from customer demands and various restrictions, all paradigms integrated implementation has become vital to manage supply chain management and supplier management. Unfortunately, there has been a limited research to provide strategies and implementation of combined technologies covering the major drawbacks and solutions to risks and problems. Therefore, a literature review related to LARG implementation with utilization of modern wireless technologies is certainly required. In order to perform this task, in Table 2 the previous researches related to this context has been done. As the potential benefits of the wireless networks are very much. The researchers are thinking about combining these paradigms with wireless technologies. But the literature review from the previous section and as mentioned in Table 2 clearly shows that the most of the wireless research has been conducted in accordance to the modes of green wireless networks because of its feasibility of reducing the harmful effects. That's why, the maximum availability of articles in regime of technology induction are related to green.

Moreover, Fig. 3 clearly elaborates that the availability of literature regarding LARG implementation is inclusive of 22 papers. However, the availability of literature for the combination of technology induction with lean is inclusive of only four related papers $[19,21-22,63]$. In fact, there is no availability of an integration of resilient and agile manufacturing with wireless technology. From a thorough study of the available literature on LARG and wireless technology implementation as visible through Table 2 and Fig. 3, it is quite evident that there is a lot of literature available on the LARG implementation but no work has been done or reported on the integration of LARG and wireless technology.

There is no doubt that an integration is certainly required to combine LARG with wireless technology

\section{Mehran University Research Journal of Engineering and Technology, vol. 39, No. 4, Uctober 2020 [p-ISSN: 0254-7821, e-ISSN: 24I3-7219]}




\section{A Lean Agile Resilient Green Implementation and Technology Utilization: A New Vision in Technology Adoption}

which will results in a totally new strategy for the future of modern manufacturing by keeping in view some of the previous researches [19,21-22,63] which certainly worked on combining paradigms with lean.

\begin{tabular}{|c|c|c|c|c|}
\hline \multicolumn{5}{|c|}{ Table 1: LARG Implementation in Manufacturing Industry } \\
\hline Author & Title & Methodology & Research Area & Findings (Authors point of views) \\
\hline $\begin{array}{l}\text { Carvalho } \\
\text { et al. }[10]\end{array}$ & $\begin{array}{l}\text { Lean, agile, resilient and } \\
\text { green: divergences and } \\
\text { synergies }\end{array}$ & Case study & $\begin{array}{l}\text { manufacturing } \\
\text { industry }\end{array}$ & $\begin{array}{l}\text { Authors explain various factors in the manufacturing } \\
\text { system focusing on the divergences between LARG } \\
\text { paradigms and their KPIs and effects on the supply chain } \\
\text { management system }\end{array}$ \\
\hline $\begin{array}{c}\text { Cabral } \\
\text { et al. [29] }\end{array}$ & $\begin{array}{l}\text { A decision-making model for } \\
\text { Lean, Agile, Resilient and } \\
\text { Green supply chain } \\
\text { management }\end{array}$ & Case study & $\begin{array}{l}\text { Automotive } \\
\text { industry }\end{array}$ & $\begin{array}{l}\text { A conceptual model based on Analytical Network } \\
\text { Process (ANP) is proposed to observe the LARG tools } \\
\text { and their KPIs on different criteria like quality, cost, } \\
\text { service, time etc. and synergic behavior of the tools on } \\
\text { SCM. }\end{array}$ \\
\hline Cabral [30] & $\begin{array}{l}\text { An Information Model for } \\
\text { Lean, Agile, Resilient and } \\
\text { Green Supply Chain } \\
\text { Management }\end{array}$ & $\begin{array}{l}\text { Literature } \\
\text { Review }\end{array}$ & $\begin{array}{l}\text { Manufacturing } \\
\text { industry }\end{array}$ & $\begin{array}{l}\text { This paper points out various parameters to be integrated } \\
\text { into the supply chain practices. Lean, agile, resilient and } \\
\text { green paradigms along with information and decision } \\
\text { making framework to predict the flow of product } \\
\text { maintaining quality, lead time reduction, customer } \\
\text { response and supplier relations are integrated the form a } \\
\text { model based implementation. }\end{array}$ \\
\hline $\begin{array}{l}\text { Mittal } \\
\text { et. al. }[31]\end{array}$ & $\begin{array}{l}\text { Adoption of Integrated Lean- } \\
\text { Green-Agile Strategies for } \\
\text { Modern Manufacturing } \\
\text { Systems }\end{array}$ & $\begin{array}{l}\text { Literature } \\
\text { review }\end{array}$ & $\begin{array}{l}\text { manufacturing } \\
\text { industry }\end{array}$ & $\begin{array}{l}\text { In this article, different analytical techniques are } \\
\text { implemented to the organizations using various enablers } \\
\text { for the adoption of combined Lean-agile-green } \\
\text { paradigms. The analytical approaches decide the } \\
\text { organizational strength, supplier selection, material } \\
\text { selection etc. to validate the best possible criteria. }\end{array}$ \\
\hline $\begin{array}{l}\text { Pham and } \\
\text { Thomas } \\
\text { [37] }\end{array}$ & $\begin{array}{l}\text { Fighting fit factories: Making } \\
\text { Industry Lean, Agile and } \\
\text { Sustainable }\end{array}$ & Theoretical & $\begin{array}{l}\text { Automotive } \\
\text { industry }\end{array}$ & $\begin{array}{l}\text { Authors explain the fit manufacturing on business as well } \\
\text { as supply chain perspective. Fit manufacturing is an } \\
\text { integration of various technology based principles and } \\
\text { measures the sustainability with respect to the market } \\
\text { trends. }\end{array}$ \\
\hline $\begin{array}{l}\text { Mollenkopf } \\
\text { et. al. [38] }\end{array}$ & $\begin{array}{c}\text { Green, lean, and global supply } \\
\text { chains }\end{array}$ & $\begin{array}{l}\text { Literature } \\
\text { review }\end{array}$ & $\begin{array}{l}\text { Manufacturing } \\
\text { industries }\end{array}$ & $\begin{array}{l}\text { Authors described various frameworks to combine lean, } \\
\text { green and global supply chain strategies and highlighted } \\
\text { the strategic approaches based on the review. They } \\
\text { suggested these frameworks for future perspectives. }\end{array}$ \\
\hline $\begin{array}{l}\text { Pham and } \\
\text { Thomas } \\
\text { [39] }\end{array}$ & $\begin{array}{l}\text { Fit manufacturing; a } \\
\text { framework for sustainability }\end{array}$ & Case study & $\begin{array}{l}\text { Manufacturing } \\
\text { industry }\end{array}$ & $\begin{array}{l}\text { This paper proposes a flexible manufacturing system } \\
\text { which can help different manufacturing enterprises in } \\
\text { achieving their economic and social goals. The proposed } \\
\text { manufacturing system is flexible enough to be adopted } \\
\text { by different enterprises to achieve sustainability and help } \\
\text { in reducing the risks which are caused by the } \\
\text { implementation of conventional techniques. }\end{array}$ \\
\hline $\begin{array}{l}\text { Carvalho } \\
\text { and Cruz- } \\
\text { Machado } \\
\quad[40]\end{array}$ & $\begin{array}{l}\text { Integrating Lean, Agile, } \\
\text { Resilience and Green } \\
\text { Paradigms in Supply Chain } \\
\text { Management (LARG_SCM) }\end{array}$ & $\begin{array}{l}\text { Literature } \\
\text { review }\end{array}$ & $\begin{array}{l}\text { Manufacturing } \\
\text { industry }\end{array}$ & $\begin{array}{l}\text { The paper first shows the pros and cons of lean, agile, } \\
\text { resilient and green strategies on supply chain and then } \\
\text { develops a model. Indicating the effect of all of these } \\
\text { strategies when implemented altogether. The effect of } \\
\text { these practices on supply chain is observed through } \\
\text { performance indicators. }\end{array}$ \\
\hline $\begin{array}{c}\text { Azevedo } \\
\text { and Cruz- } \\
\text { Machado } \\
\text { [41] }\end{array}$ & $\begin{array}{l}\text { Influence of Lean, Resilient } \\
\text { and Green Practices on Supply } \\
\text { Chain Sustainability }\end{array}$ & $\begin{array}{l}\text { Literature } \\
\text { review }\end{array}$ & $\begin{array}{l}\text { Manufacturing } \\
\text { industry }\end{array}$ & $\begin{array}{l}\text { Author extracts the social, economic and environmental } \\
\text { impacts of lean, green and resilient practices from } \\
\text { literature and present in the form of model. This paper } \\
\text { highlights the importance of supply chain for } \\
\text { competition and also the gap of social impacts of lean, } \\
\text { green and resilient practices present in literature. }\end{array}$ \\
\hline $\begin{array}{l}\text { Carvalho } \\
\text { et al. }[42]\end{array}$ & $\begin{array}{l}\text { Agile and resilient approaches } \\
\text { to supply chain management: } \\
\text { influence on performance and } \\
\text { competitiveness }\end{array}$ & $\begin{array}{l}\text { Literature } \\
\text { review }\end{array}$ & $\begin{array}{l}\text { Manufacturing } \\
\text { industry }\end{array}$ & $\begin{array}{l}\text { This paper shows the agile and resilient supply chain } \\
\text { management practices (applied in upstream, daily } \\
\text { internal operations and downstream manner) and } \\
\text { highlights the indicators to check effect of agile and } \\
\text { resilient practices on supply chain management. Author } \\
\text { presents a comprehensive conceptual model for a better } \\
\text { supply chain management system after thoroughly } \\
\text { understanding the effects of agile and resilient practices } \\
\text { separately and in combined effect. }\end{array}$ \\
\hline $\begin{array}{l}\text { Chiarini } \\
\text { [43] }\end{array}$ & $\begin{array}{l}\text { Sustainable manufacturing- } \\
\text { greening processes using } \\
\text { specific Lean Production tools: }\end{array}$ & Case study & $\begin{array}{l}\text { Motorcycle } \\
\text { industry }\end{array}$ & $\begin{array}{l}\text { The paper highlights the implementation of five lean } \\
\text { tools: VSM, cellular manufacturing, } 5 \mathrm{~S} \text {, TPM and }\end{array}$ \\
\hline
\end{tabular}




\section{A Lean Agile Resilient Green Implementation and Technology Utilization: A New Vision in Technology Adoption}

\begin{tabular}{|c|c|c|c|c|}
\hline & $\begin{array}{l}\text { An empirical observation from } \\
\text { European motorcycle } \\
\text { component manufacturers }\end{array}$ & & & $\begin{array}{l}\text { SMED to predict the impacts on environmental } \\
\text { performance and compares the tools efficiencies. }\end{array}$ \\
\hline $\begin{array}{l}\text { Govindan } \\
\text { et al. }[44]\end{array}$ & $\begin{array}{l}\text { Impact of supply chain } \\
\text { management practices on } \\
\text { sustainability }\end{array}$ & $\begin{array}{l}\text { conceptual } \\
\text { model }\end{array}$ & $\begin{array}{l}\text { Automotive } \\
\text { industry }\end{array}$ & $\begin{array}{l}\text { Authors explain the integration of lean, green and } \\
\text { resilient practices using hypothesis to construct a model } \\
\text { which highlights combined impacts on all sustainability } \\
\text { dimensions. Model based study is done based on } 5 \text { case } \\
\text { studies on automotive supply chain. }\end{array}$ \\
\hline $\begin{array}{l}\text { Azfar } \\
\text { et al. }[45]\end{array}$ & $\begin{array}{l}\text { Performance measurement, a } \\
\text { conceptual framework for } \\
\text { supply chain practices }\end{array}$ & $\begin{array}{l}\text { Literature } \\
\text { review }\end{array}$ & $\begin{array}{l}\text { Manufacturing } \\
\text { industry }\end{array}$ & $\begin{array}{l}\text { Author highlights the parameters for measuring the } \\
\text { efficiency and performance of the implemented } \\
\text { techniques. This paper presents the conceptual } \\
\text { framework for the implementation of LARG practices } \\
\text { and for the measurement of its impact on the supply chain }\end{array}$ \\
\hline $\begin{array}{l}\text { Mari et al. } \\
\quad[46]\end{array}$ & $\begin{array}{l}\text { Sustainable and Resilient } \\
\text { Supply Chain Network Design } \\
\text { under Disruption Risks }\end{array}$ & $\begin{array}{l}\text { Literature } \\
\text { review/Case } \\
\text { study }\end{array}$ & $\begin{array}{l}\text { Garment } \\
\text { industry }\end{array}$ & $\begin{array}{l}\text { Author presents a model for making a resilient } \\
\text { sustainable system that can withstand different types of } \\
\text { disruptions and then perform weighted analysis to reduce } \\
\text { the deviation of variables from the goals of casts, } \\
\text { emission and resilient sustainability }\end{array}$ \\
\hline $\begin{array}{l}\text { Govindan } \\
\text { et al. }[47]\end{array}$ & $\begin{array}{l}\text { Lean, green and resilient } \\
\text { practices influence on supply } \\
\text { chain performance: } \\
\text { interpretive structural } \\
\text { modeling approach }\end{array}$ & $\begin{array}{l}\text { Conceptual } \\
\text { model }\end{array}$ & $\begin{array}{l}\text { Automotive } \\
\text { industry }\end{array}$ & $\begin{array}{l}\text { This paper suggests the interrelations on lean, resilient } \\
\text { and green practices based on interpretive structural } \\
\text { model and classifies the practices on structural self- } \\
\text { interaction matrix by detailing the dependencies of } \\
\text { practices on each other }\end{array}$ \\
\hline $\begin{array}{l}\text { Soltan and } \\
\text { Mostafa } \\
\text { [48] }\end{array}$ & $\begin{array}{l}\text { Lean and agile performance } \\
\text { framework for manufacturing } \\
\text { enterprises }\end{array}$ & $\begin{array}{l}\text { Literature } \\
\text { review }\end{array}$ & $\begin{array}{l}\text { Manufacturing } \\
\text { organization }\end{array}$ & $\begin{array}{l}\text { Combination of lean and agile by decoupling points } \\
\text { improves benefits and explains a broad method for } \\
\text { analyzing performance on enterprise level as healthy } \\
\text { organization but its success depends on consideration of } \\
\text { the challenges that enterprise may face. }\end{array}$ \\
\hline $\begin{array}{l}\text { Sohi et al. } \\
\quad[49]\end{array}$ & $\begin{array}{l}\text { Does lean \& agile project } \\
\text { management help coping with } \\
\text { project complexity? }\end{array}$ & Survey & $\begin{array}{l}\text { Construction } \\
\text { projects }\end{array}$ & $\begin{array}{l}\text { Combination of lean and agile in construction project } \\
\text { management is promising to handle the complexity and } \\
\text { its improvements. }\end{array}$ \\
\hline $\begin{array}{l}\text { do Rosário } \\
\text { Cabrita } \\
\text { et al. }[50]\end{array}$ & $\begin{array}{l}\text { Integration of lean, agile, } \\
\text { resilient and green paradigm in } \\
\text { a business model Perspective: } \\
\text { Theoretical Foundations }\end{array}$ & $\begin{array}{l}\text { Literature } \\
\text { review }\end{array}$ & $\begin{array}{l}\text { Manufacturing } \\
\text { industry }\end{array}$ & $\begin{array}{l}\text { Author developed a business model having nine } \\
\text { components and then comprehensively detailed the } \\
\text { comparison/effect of each component with the LARG } \\
\text { practice this paper highlight the gap present for the } \\
\text { intersection of business model and LARG practice. }\end{array}$ \\
\hline $\begin{array}{l}\text { Ruiz- } \\
\text { Benitez } \\
\text { et al. }[51]\end{array}$ & $\begin{array}{l}\text { Environmental benefits of } \\
\text { lean, green and resilient supply } \\
\text { chain management: the case of } \\
\text { the aerospace sector }\end{array}$ & Case study & $\begin{array}{l}\text { Aerospace } \\
\text { sector }\end{array}$ & $\begin{array}{l}\text { Authors explain the synergic implementation of lean, } \\
\text { green and resilient and their effects on environment } \\
\text { based on two approaches: Importance-performance } \\
\text { analysis (IPA) and Interpretive Structural Modeling } \\
\text { (ISM) to solve complex matrix of implementation of } \\
\text { practices. }\end{array}$ \\
\hline $\begin{array}{l}\text { Ciccullo } \\
\text { et al. }[52]\end{array}$ & $\begin{array}{l}\text { Integrating the environmental } \\
\text { and social sustainability pillars } \\
\text { into the lean and agile supply } \\
\text { chain management paradigms: } \\
\text { A literature review and future } \\
\text { research directions }\end{array}$ & $\begin{array}{l}\text { Literature } \\
\text { review }\end{array}$ & $\begin{array}{l}\text { Manufacturing } \\
\text { industry }\end{array}$ & $\begin{array}{l}\text { A review has been conducted in this paper in which the } \\
\text { selected paradigms are investigated and categorized } \\
\text { based on dependencies on each other and it provides the } \\
\text { cumulative study for future researches. }\end{array}$ \\
\hline $\begin{array}{l}\text { Salvador } \\
\text { et al. }[53]\end{array}$ & $\begin{array}{c}\text { Approach of the Two-way } \\
\text { Influence Between Lean and } \\
\text { Green Manufacturing and its } \\
\text { Connection to Related } \\
\text { Organizational Areas } \\
\end{array}$ & $\begin{array}{l}\text { Literature } \\
\text { review }\end{array}$ & $\begin{array}{l}\text { Manufacturing } \\
\text { industry }\end{array}$ & $\begin{array}{l}\text { A review presents synergic and complementary relation } \\
\text { between lean and green manufacturing and shows after- } \\
\text { effects of these paradigms in various organizational } \\
\text { perspectives. }\end{array}$ \\
\hline $\begin{array}{l}\text { Cherrafi } \\
\text { et al. }[54]\end{array}$ & $\begin{array}{l}\text { A framework for the } \\
\text { integration of green and lean } \\
\text { six sigma for superior } \\
\text { sustainability performance }\end{array}$ & $\begin{array}{l}\text { Literature } \\
\text { review/case } \\
\text { study }\end{array}$ & $\begin{array}{l}\text { Manufacturing } \\
\text { industry }\end{array}$ & $\begin{array}{l}\text { This paper contains } 4 \text { phases for the implementation of } \\
\text { lean six-sigma technique and in each phase the necessary } \\
\text { required drivers, parameters and indicators are } \\
\text { highlighted. Author shows the result after } \\
\text { implementation of this technique in defined } 4 \text { phases on } \\
\text { four different companies. }\end{array}$ \\
\hline $\begin{array}{c}\text { Azfar } \\
\text { et al. [55] }\end{array}$ & $\begin{array}{l}\text { Application of Lean Agile } \\
\text { Resilient Green Paradigm } \\
\text { Framework on China Pakistan } \\
\text { Economic Corridor: A Case } \\
\text { Study }\end{array}$ & Case Study & $\begin{array}{l}\text { Manufacturing } \\
\text { industry }\end{array}$ & $\begin{array}{l}\text { Scenario planning for four routes is proposed fulfilling } \\
\text { the supply chain attributes with CPEC study as } \\
\text { benchmark }\end{array}$ \\
\hline
\end{tabular}




\begin{tabular}{|c|c|c|c|c|c|c|c|c|c|c|c|}
\hline \multicolumn{12}{|c|}{ Table 2: Technology in LARG Implementation } \\
\hline$\dot{\mathrm{z}}$ & 总 & 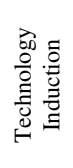 & : & 者 & $\begin{array}{l}\text { 苟 } \\
: \overline{0} \\
\simeq\end{array}$ & ปี & $\begin{array}{l}\text { के } \\
\frac{0}{0} \\
0 \\
0 \\
0 \\
\frac{0}{0} \\
\sum\end{array}$ & 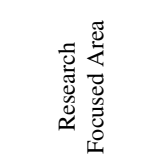 & 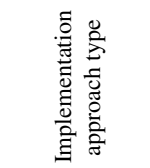 & 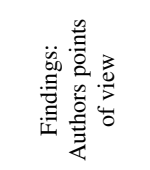 & 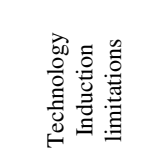 \\
\hline 1. & $\begin{array}{c}\text { Jasti and } \\
\text { Kodali [21] }\end{array}$ & Yes & $\bullet$ & & & & Literature review & $\begin{array}{l}\text { Implementation } \\
\text { framework }\end{array}$ & $\begin{array}{c}\text { A pillar based } \\
\text { framework for } \\
\text { lean } \\
\text { implementation }\end{array}$ & $\begin{array}{c}\text { Used pillars to } \\
\text { design } \\
\text { framework and } \\
\text { IT system } \\
\end{array}$ & $\begin{array}{c}\text { Conceptual stage } \\
\text { framework } \\
\text { without } \\
\text { validation } \\
\end{array}$ \\
\hline 2. & $\begin{array}{c}\text { Jasti and } \\
\text { Kodali [22] }\end{array}$ & Yes & $\bullet$ & & & & Literature review & $\begin{array}{l}\text { Implementation } \\
\text { framework }\end{array}$ & $\begin{array}{l}\text { A pillar based } \\
\text { framework to } \\
\text { attain } \\
\text { improvement } \\
\text { in production }\end{array}$ & $\begin{array}{c}\text { Used pillars to } \\
\text { design } \\
\text { framework and } \\
\text { IT system was } \\
\text { one of the } \\
\text { pillars }\end{array}$ & $\begin{array}{l}\text { No validation } \\
\text { done and } \\
\text { framework was in } \\
\text { conceptual phase }\end{array}$ \\
\hline 3. & $\begin{array}{l}\text { Chowdhury } \\
\text { et al. [56] }\end{array}$ & Yes & & & & $\bullet$ & $\begin{array}{l}\text { Theoretical } \\
\text { ramework }\end{array}$ & $\begin{array}{c}\text { Green hybrid } \\
\text { wireless-optical } \\
\text { broadband access } \\
\text { network } \\
\text { (WOBAN) }\end{array}$ & $\begin{array}{l}\text { Reduction of } \\
\text { energy usage in } \\
\text { the wireless } \\
\text { networks } \\
\text { without } \\
\text { effecting the } \\
\text { performance } \\
\text { quality } \\
\text { considerably, } \\
\text { using different } \\
\text { energy- aware } \\
\text { WOBAN by } \\
\text { considering a } \\
\text { mixed integer } \\
\text { linear program } \\
\text { (MILP) model } \\
\text { as benchmark. }\end{array}$ & $\begin{array}{c}\text { Using proper } \\
\text { designing } \\
\text { constraints } \\
\text { reduction in } \\
\text { energy usage } \\
\text { can be obtained } \\
\text { by energy- } \\
\text { aware mode } \\
\text { without } \\
\text { compromising } \\
\text { the network } \\
\text { performance } \\
\text { quality } \\
\text { considerably. } \\
\text { These energy- } \\
\text { aware } \\
\text { techniques also } \\
\text { can be } \\
\text { generalized for } \\
\text { their use in } \\
\text { other networks. }\end{array}$ & $\begin{array}{l}\text { Analyzing the } \\
\text { working of green } \\
\text { WOBAN with } \\
\text { through practical } \\
\text { implementation. }\end{array}$ \\
\hline 4. & $\begin{array}{l}\text { Wang } \\
\text { et al. } \\
{[57]}\end{array}$ & Yes & & & & $\bullet$ & $\begin{array}{l}\text { Theoretical } \\
\text { analysis } \\
\text { Simulation And } \\
\text { experimentation }\end{array}$ & $\begin{array}{l}\text { Green wireless } \\
\text { communications }\end{array}$ & $\begin{array}{l}\text { Transmission } \\
\text { systems which } \\
\text { are based on } \\
\text { TR can be a } \\
\text { perfect solution } \\
\text { for green } \\
\text { communication } \\
\text { as they can } \\
\text { harvest energy } \\
\text { from } \\
\text { environment } \\
\text { and causing } \\
\text { less } \\
\text { interference to } \\
\text { other receivers. }\end{array}$ & $\begin{array}{l}\text { The results } \\
\text { reveal that TR } \\
\text { systems have } \\
\text { ability for } \\
\text { reduction in } \\
\text { power usage } \\
\text { and alleviation } \\
\text { in interference } \\
\text { as well as } \\
\text { highly gain in } \\
\text { multi-path } \\
\text { diversity. It was } \\
\text { shown by both } \\
\text { simulation and } \\
\text { experimental } \\
\text { values. } \\
\end{array}$ & $\begin{array}{c}\text { The efficiency of } \\
\text { TR based systems } \\
\text { need to be } \\
\text { investigated in } \\
\text { many different } \\
\text { environment and } \\
\text { along with } \\
\text { integration with } \\
\text { other techniques } \\
\text { e.g. lean, agile } \\
\text { and resilient. }\end{array}$ \\
\hline 5. & $\begin{array}{c}\text { Bu et al. } \\
{[58]}\end{array}$ & Yes & & & & $\bullet$ & Simulation & $\begin{array}{l}\text { Green wireless } \\
\text { cellular networks }\end{array}$ & $\begin{array}{l}\text { Minimizing the } \\
\text { operational } \\
\text { expenditure and } \\
\text { reducing the } \\
\text { environmental } \\
\text { pollution } \\
\text { problems by the } \\
\text { reduction of } \\
\mathrm{CO}_{2} \text { emission } \\
\text { by utilizing the } \\
\text { proposed } \\
\text { scheme. }\end{array}$ & $\begin{array}{l}\text { The results } \\
\text { obtained from } \\
\text { simulations } \\
\text { shown that } \\
\text { green wireless } \\
\text { networks are } \\
\text { significantly } \\
\text { affected by } \\
\text { smart grids and } \\
\text { the proposed } \\
\text { scheme can } \\
\text { help in } \\
\text { reduction of } \\
\text { operational cost } \\
\text { and CO2 } \\
\text { emissions for } \\
\text { green wireless } \\
\text { networks. }\end{array}$ & $\begin{array}{l}\text { The proposed } \\
\text { framework with } \\
\text { the heterogeneous } \\
\text { wireless networks } \\
\text { with femtocells } \\
\text { needs to be } \\
\text { considered. The } \\
\text { practical } \\
\text { application of } \\
\text { proposed solution } \\
\text { needs to be } \\
\text { verified. }\end{array}$ \\
\hline 6. & $\begin{array}{c}\text { Suarez } \\
\text { et al. } \text { [59] }\end{array}$ & Yes & & & & $\bullet$ & Literature review & $\begin{array}{l}\text { Green wireless } \\
\text { networks }\end{array}$ & $\begin{array}{c}\text { Summarizing } \\
\text { the metrics } \\
\text { used in relevant } \\
\text { literature for it } \\
\text { evaluation and } \\
\text { focused on } \\
\text { current } \\
\text { proposal } \\
\text { (power } \\
\text { amplification, } \\
\text { cell layout } \\
\text { adaptation and } \\
\text { additionally } \\
\text { management of } \\
\text { radio resources }\end{array}$ & $\begin{array}{c}\text { None single } \\
\text { trend presented } \\
\text { in the literature } \\
\text { is enough and it } \\
\text { requires a } \\
\text { joined approach } \\
\text { as it was } \\
\text { presented in the } \\
\text { proposal. A } \\
\text { good hard work } \\
\text { is required to } \\
\text { obtain the goals } \\
\text { of energy } \\
\text { reduction and it } \\
\text { is expected that }\end{array}$ & $\begin{array}{l}\text { Combining many } \\
\text { of the proposals } \\
\text { and } \\
\text { considerations of } \\
\text { many others } \\
\text { aspects e.g. cost } \\
\text { effectiveness } \\
\text { should also be } \\
\text { considered. The } \\
\text { practical } \\
\text { implementation } \\
\text { of many research } \\
\text { in case of green } \\
\text { networks is } \\
\text { essential. } \\
\end{array}$ \\
\hline
\end{tabular}


A Lean Agile Resilient Green Implementation and Technology Utilization: A New Vision in Technology Adoption

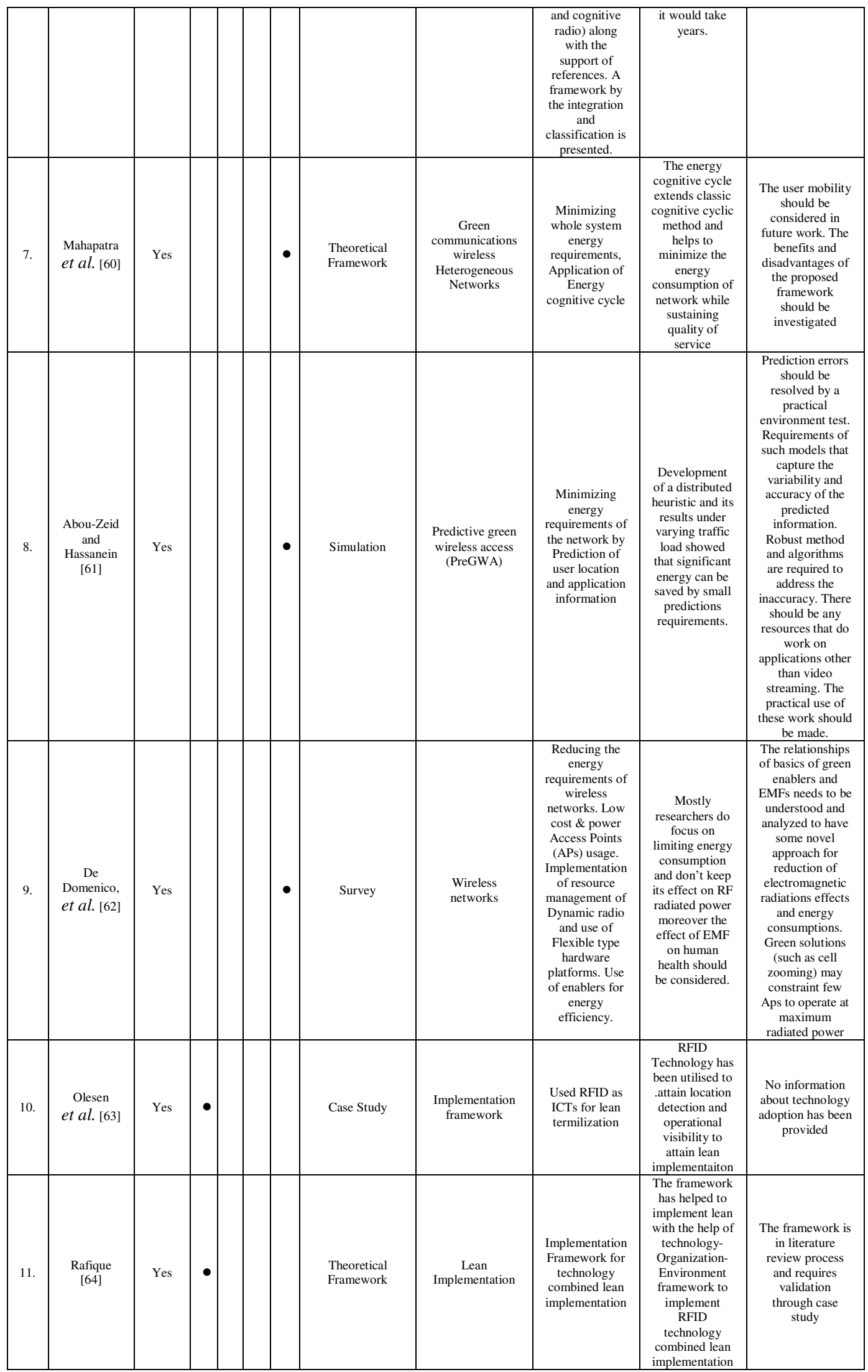


A Lean Agile Resilient Green Implementation and Technology Utilization: A New Vision in Technology Adoption

\begin{tabular}{|c|c|c|c|c|c|c|c|c|}
\hline 12. & $\begin{array}{c}\text { Gandotra } \\
\text { and Jha } \\
\text { [65] }\end{array}$ & Yes & $\bullet$ & Survey & $\begin{array}{c}\text { Green } \\
\text { communication }\end{array}$ & $\begin{array}{c}\text { Different } \\
\text { energy-efficient } \\
\text { setups for green } \\
\text { communication } \\
\text {. Proposal of a } \\
\text { three-layer } \\
\text { architecture } \\
\text { that highlights } \\
\text { information } \\
\text { transmission } \\
\text { through relays. } \\
\text { Enumeration of } \\
\text { secure power } \\
\text { optimization of } \\
\text { relays }\end{array}$ & $\begin{array}{l}\text { The use of } \\
\text { energy efficient } \\
\text { systems for } \\
\text { green wireless } \\
\text { technology are } \\
\text { essential for } \\
\text { reducing } \\
\text { energy } \\
\text { consumption } \\
\text { and } \mathrm{CO}_{2} \\
\text { addition in } \\
\text { environment } \\
\text { moreover the } \\
\text { use of network } \\
\text { security is also } \\
\text { an important } \\
\text { parameter in } \\
\text { green network }\end{array}$ & $\begin{array}{c}\text { In future there } \\
\text { will be much } \\
\text { more need of } \\
\text { wireless } \\
\text { networks, as a } \\
\text { result there would } \\
\text { be more } \\
\text { radiations effects } \\
\text { more } \mathrm{CO}_{2} \\
\text { production and } \\
\text { more energy } \\
\text { requirements, so } \\
\text { there must be any } \\
\text { solution of these } \\
\text { problems such as } \\
\text { green } \\
\text { communication } \\
\text { networks to avoid } \\
\text { these future } \\
\text { problems. }\end{array}$ \\
\hline 13. & $\begin{array}{c}\text { Wang } \\
\text { et al. }[66]\end{array}$ & Yes & $\bullet$ & $\begin{array}{l}\text { Mathematical } \\
\text { model }\end{array}$ & Green wireless & $\begin{array}{l}\text { Reducing the } \\
\text { total cost of } \\
\text { energy in } \\
\text { heterogeneous } \\
\text { green wireless } \\
\text { network by the } \\
\text { application of } \\
\text { hybrid energy. } \\
\text { Using a } \\
\text { mathematical } \\
\text { modeling for } \\
\text { problem } \\
\text { solving. }\end{array}$ & $\begin{array}{l}\text { The result from } \\
\text { simulation } \\
\text { described that } \\
\text { the proposed } \\
\text { solution has } \\
\text { much } \\
\text { effectiveness in } \\
\text { energy cost } \\
\text { reduction in } \\
\text { comparison } \\
\text { with peer } \\
\text { algorithms. } \\
\text { And it has less } \\
\text { operational } \\
\text { complexity. }\end{array}$ & $\begin{array}{l}\text { The practical } \\
\text { implementation } \\
\text { of this } \\
\text { mathematical } \\
\text { model still need } \\
\text { investigation. }\end{array}$ \\
\hline 14. & $\begin{array}{c}\text { Dahal } \\
\text { et al. }[67]\end{array}$ & Yes & $\bullet$ & Experimentation & $\begin{array}{c}\text { Green wireless } \\
\text { technology }\end{array}$ & $\begin{array}{c}\text { Turning } \\
\text { automatically } \\
\text { power on and } \\
\text { off unnecessary } \\
\text { transmitters on } \\
\text { low and higher } \\
\text { traffic } \\
\text { conditions }\end{array}$ & $\begin{array}{l}\text { This technique } \\
\text { enables } \\
\text { dynamic } \\
\text { adjustment of } \\
\text { number of } \\
\text { transmitters as } \\
\text { requirements } \\
\text { without } \\
\text { effecting } \\
\text { service quality } \\
\text { and reduction } \\
\text { of energy } \\
\text { consumption up } \\
\text { to } 18.8 \% \text { as } \\
\text { compared to } \\
\text { traditional } \\
\text { system and also } \\
\text { reduces } \\
\text { environmental } \\
\text { effects. }\end{array}$ & $\begin{array}{l}\text { For the future } \\
\text { there will be } \\
\text { more necessity } \\
\text { for developing } \\
\text { cell zooming } \\
\text { technology in } \\
\text { heterogeneous } \\
\text { network and for } \\
\text { the wireless } \\
\text { technology based } \\
\text { on green. }\end{array}$ \\
\hline
\end{tabular}

\section{Literature Availability}

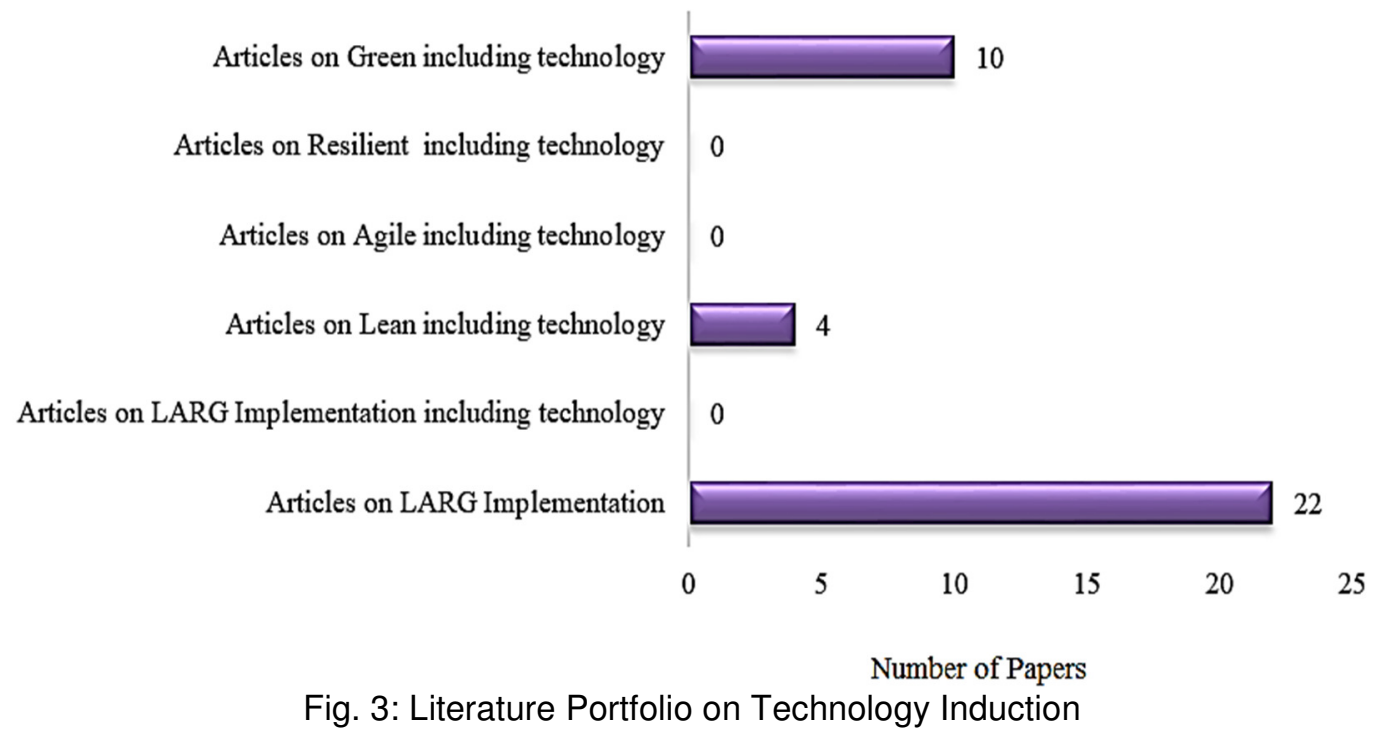




\section{CONCLUSION}

Lean Manufacturing is one of the process for improvement in manufacturing industries especially in deem of adoption towards Lean. Recently it has been noticed that lean manufacturing holds much significance in reducing the non-value adding processes but this practice does not assure the long term sustainability of the manufacturing industry. The quest of industries to achieve long-term sustainability spectacles that only lean is not enough to compete continuously varying trend of market, in such environment, industries are looking towards new and advance paradigms like, Agile, Resilient and Green either separate or in combined form as LARG to achieve goals. The concept of LARG is synchronized combination of lean, agile, resilient and green in the most suitable way to achieve the benefits of all these tools and reduce their divergence as much as possible. The main problem is to synchronize all tools together in which the utilization of wireless technology can play a vital role. However, the synchronization of LARG and then combination of LARG with technology is not an easy task as these technologies have much dissimilarity in their working. Therefore, based on this ideology, the aim of this study is to collect and study previous data available on LARG and search for the utilization of LARG with wireless technology. The first objective states that many researchers have done a lot of effort to utilize the meaningful combination of these techniques in the form of comprehensive framework/models on LARG which unfortunately covers various domains of manufacturing industries and try to maximize the synergic benefits of these four techniques and reduce their divergence to a minimum possible point. There is no doubt that this ideology has helped organizations in finding potential areas where more profit and longterm sustainability can be achieved in the hostile environment of market. However, in second objective, which is looking towards the advanced techniques of LARG in combination with wireless technology, there is availability of data in case of green and Lean, and shows the dearth of data availability for the utilization of LARG with wireless technology which is need of present era and many organizations have recognized this advanced combined technique as a useful and beneficial tool. In fact, it ascertains lack of data for the implementation and modernization of LARG that is the requirement of practitioners and academicians working on the LARG to attain modernized manufacturing.

\section{ACKNOWLEDGEMENT}

The authors of this research study are highly thankful to The University of Lahore, Lahore, Pakistan, for providing us the platform and facilities to conduct this research.

\section{REFERENCES}

[1] Stroeken, J., "Information Technology, Innovation and Supply Chain Structure", International Journal of Technology Management, Vol. 20, No. 1/2, pp. 156-175, 2000.

[2] Sharifi, H., and Zhang, Z., "A Methodology for Achieving Agility in Manufacturing Organizations: An Introduction", International Journal of Production Economics, Vol. 62, No. 1-2, pp. 7-22, 1999.

[3] Slack, N., "Flexibility as a Manufacturing Objective", International Journal of Operations and Production Management, Vol. 3, No. 3, pp. 4-13, 1983.

[4] Swafford, M., Ghosh, S., and Murthy, N., "Achieving Supply Chain Agility Through IT Integration and Flexibility", International Journal of Production Economics, Vol. 116, No. 2, pp. 288-297, 2008.

[5] Ponomarov, Y., and holcomb, C., "Understanding The Concept of Supply Chain Resilience", The International Journal of Logistics Management, Vol. 20, No. 1, pp. 124-143, 2009.

[6] Bhamra, R., Dani, S. and Burnard, K., "Resilience: The Concept, A Literature Review and Future Directions", International Journal of Production Research, Vol. 49, No. 18, pp. 5375-5393, 2011.

[7] Carter, R., and Rogers, S., "A Framework of Sustainable Supply Chain Management: 
Moving Toward New Theory", International Journal of Physical Distribution and Logistics Management, Vol. 38, No. 5, pp. 360-387, 2008.

[8] Paul, I., Bhole, G., and Chaudhari, J., "A Review On Green Manufacturing: It's Important, Methodology And Its Application", Procedia Materials Science, Vol. 6, pp. 1644-1649, 2014.

[9] Sangari, S., Ramzi, J., and Zolfaghari, S., "Developing A Practical Evaluation Framework for Identifying Critical Factors to Achieve Supply Chain Agility", Measurement, Vol. 62, pp. 205-214, 2015.

[10] Carvalho, H., Duarte, S., and Cruzmachado, V., "Lean, Agile, Resilient And Green: Divergences And Synergies", International Journal of Lean Six Sigma, Vol. 2, No. 2, pp. 151-179, 2011.

[11] Yaakub, S., and Mustafa, K., "Supply Chain Risk Management for The Sme's", Academic Journal of Interdisciplinary Studies, Vol. 4, No. 1 S2, p. 151, 2015.

[12] Sarkis, J., "Benchmarking for agility", Benchmarking: An International Journal, Vol. 8, No. 2, pp. 88-107, 2001.

[13] Shah, R., and Ward, P., "Lean Manufacturing: Context, Practice Bundles, And Performance", Journal of Operations Management, Vol. 21, No. 2, pp. 129-149, 2003.

[14] Tseng, Y., and Lin, C., "Enhancing Enterprise Agility by Deploying Agile Drivers, Capabilities and Providers", Information Sciences, Vol. 181, No. 17, pp. 3693-3708, 2011.

[15] Carvalho, H., Azevedo, G., and Cruzmachado, V., "An Innovative Agile and Resilient Index for The Automotive Supply Chain", International Journal of Agile Systems and Management, Vol. 6, No. 3, pp. 259-283, 2013.

[16] Hallgren, M., and Olhager, J., "Lean and Agile Manufacturing: External and Internal Drivers and Performance Outcomes", International Journal of Operations and Production Management, Volume 29, No. 10, pp. 976-999, 2009.
Chavez, R., Gimenez, C., Fynes, B., Wiengarten, F., and Yu, W., "Internal Lean Practices and Operational Performance: The Contingency Perspective of Industry Clock speed", International Journal of Operations \& Production Management, Vol. 33, No. 5, pp. 562-588, 2013.

[18] Eckstein, D., Goellner, M., Blome, C., and Henke, M., "The Performance Impact of Supply Chain Agility and Supply Chain Adaptability: The Moderating Effect of Product Complexity", International Journal of Production Research, Vol. 53, No. 10, pp. 3028-3046, 2015.

[19] Rafique, M., Ab Aahman, M., Saibani, N., and arsad, N., "A Systematic Review of Lean Implementation Approaches-A Proposed chnology Combined Lean Implementation Framework", Total Quality Management and Business Excellence, Vol. 30, No. 3-4, pp. 386-421, 2017.

[20] Rafique, M., Ab Aahman, M., Saibani, N., Arsad, N., and Saadat, W., "RFID Impacts On Barriers Affecting Lean Manufacturing", Industrial Management and Data Systems, Vol. 116, No. 8, pp.1585-1616, 2016

[21] Jasti, N., and Kodali, R., "A Critical Review of Lean Supply Chain Management Frameworks: Proposed Framework", Production Planning and Control, Vol. 26, pp.1051-1068, 2015

[22] Jasti, N., and Kodali, R., "Development of A Framework for Lean Production System: An Integrative Approach", Proceedings of the Institution of Mechanical Engineers, Part B: Journal of Engineering Manufacture, Vol. 230, No. 1, pp. 136-156, 2016.

[23] Jasti, N., and Kodali, R., "Lean Production: Literature Review and Trends", International Journal of Production Research, Vol. 53, No. 3, pp. 867-885, 2015.

[24] Jadhav, J., Mantha, S., and Rane, S., "Exploring Barriers in Lean Implementation", International Journal of Lean Six Sigma, Vol. 5, No. 2, pp. 122-148, 2014.

[25] Kitchenham, B., and Brereton, P., "A Systematic Review Of Systematic Review 
Process Research In Software Engineering", Information and Software Technology, Vol. 55, No. 12, pp. 2049-2075, 2013.

[26] Green, B., Johnson, C., and Adams, A., "Writing Narrative Literature Reviews for Peer-Reviewed Journals: Secrets of The Trade", Journal of Chiropractic Medicine, Vol. 5, No. 3, pp. 101-117, 2006.

[27] Mostafa, S., Dumrak, J., and Soltan, H., "A Framework for Lean Manufacturing Implementation", Production and Manufacturing Research, Vol. 1, No. 1, pp. 44-64, 2013.

[28] Morash, E., "Supply Chain Strategies, Capabilities, And Performance", Transportation Journal, pp. 37-54, Vol. 41, No. 1, pp. 37-54,2001.

[29] Cabral, I., Grilo, A., and Cruz-Machado, V., "A Decision-Making Model for Lean, Agile, Resilient and Green Supply Chain Management", International Journal of Production Research, Vol. 50, No. 17, pp. 4830-4845, 2012.

[30] I. F. Cabral, "An Information Model for Lean, Agile, Resilient and Green Supply Chain Management", Faculdade de Ciências e Tecnologia, 2011.

[31] Mittal, V., Sindhwani, R., Kalsariya, V., Salroo, F., Sangwan, K., and Singh, P., "Adoption of Integrated Lean-Green-Agile Strategies for Modern Manufacturing Systems", Procedia CIRP, Vol. 61, pp. 463468, 2017.

[32] Verrier, B., Rose, B., Caillaud, E., and Remita, H., "Combining Organizational Performance with Sustainable Development Issues: The Lean and Green Project Benchmarking Repository", Journal of Cleaner Production, Vol. 85, pp. 83-93, 2014.

[33] Yang, M., Hong, P., and Modi, S., "Impact of Lean Manufacturing and Environmental Management On Business Performance: An Empirical Study of Manufacturing Firms", International Journal of Production Economics, Vol. 129, No. 2, pp. 251-261, 2011.

[34] Kornbluh, H., Crowfoot, J., and CohenRosenthal, E., "Worker Participation in
Energy and Natural Resources Conservation", Int'l Lab. Rev., Vol. 124, p. 737, 1985.

[35] A. Goyal and R. Agrawal, "Advanced Manufacturing Management System for Environmental Sustainability- A Review of Select Literature", International Journal of Global Business and Competitiveness, Vol. 12, No. 1, pp. 1-11, 2017.

[36] Orboi, M., Băneş, A., Petroman, I., Monea, M., and Bălan, I., "Sociological Dimensions of Sustainable Development", Research Journal of Agricultural Science, Vol. 42, No. 3, pp. 749-755, 2010.

[37] Pham, D., and Thomas, A., "Fighting Fit Factories: Making Industry Lean, Agile and Sustainable", Manufacturing Engineer, Vol. 84, No. 2, pp. 24-29, 2005.

[38] Mollenkopf, D., Stolze, H., Tate, W., and Ueltschy, M., "Green, Lean, And Global Supply Chains", International Journal of Physical Distribution and Logistics Management, Vol. 40, No. 1/2, pp. 14-41, 2010.

[39] Pham, D., and Thomas, A., "Fit Manufacturing: A Framework for Sustainability", Journal of Manufacturing Technology Management, Vol. 23, No. 1, pp. 103-123, 2011.

[40] H. Carvalho and V. Cruz-Machado, "Integrating Lean, Agile, Resilience and Green Paradigms in Supply Chain Management (Larg_Scm)", Supply Chain Management: InTech, 2011.

[41] Azevedo, S., and Cruz-machado, V., "Influence of Lean, Resilient and Green Practices On Supply Chain Sustainability", Management, Vol. 15, p. 19, 2012.

[42] Carvalho, H., Azevedo, S., and CruzMachado, V., "Agile and Resilient Approaches to Supply Chain Management: Influence On Performance and Competitiveness", Logistics Research, Vol. 4, No. 1-2, pp. 49-62, 2012.

[43] Chiarini, A., "Sustainable ManufacturingGreening Processes Using Specific Lean Production Tools: An Empirical Observation from European Motorcycle Component 
Manufacturers", Journal of Cleaner Production, Vol. 85, pp. 226-233, 2014.

[44] Govindan, K., Azevedo, S., Carvalho, H., and Cruzmachado, V., "Impact of Supply Chain Management Practices On Sustainability", Journal of Cleaner Production, Vol. 85, pp. 212-225, 2014.

[45] Azfar, K., Khan, N., and Gabriel, H., "Performance Measurement: A Conceptual Framework for Supply Chain Practices", Procedia-Social and Behavioral Sciences, Vol. 150, pp. 803-812, 2014.

[46] Mari, S. Lee, Y., and Memon, M, "Sustainable and Resilient Supply Chain Network Design Under Disruption Risks", Sustainability, Vol. 6, No. 10, pp. 6666-6686, 2014.

[47] Govindan, K., Azevedo, S., Carvalho, H., and Cruz-Machado, V., "Lean, Green and Resilient Practices Influence On Supply Chain Performance: Interpretive Structural Modeling Approach", International Journal of Environmental Science and Technology, Vol. 12, No. 1, pp. 15-34, 2015.

[48] Soltan, H., and Mostafa, S., "Lean and Agile Performance Framework for Manufacturing Enterprises", Procedia Manufacturing, Vol. 2, pp. 476-484, 2015.

[49] Sohi, A., Hertogh, M., Bosch-Rekveldt, M., and Blom, R., "Does Lean \& Agile Project Management Help Coping with Project Complexity?", Procedia-Social and Behavioral Sciences, Vol. 226, pp. 252-259, 2016.

[50] Cabrita, M., Duarte, S., Carvalho, H., and Cruz-Machado, V., "Integration of Lean, Agile, Resilient and Green Paradigms in a Business Model Perspective: Theoretical Foundations", IFAC, Vol. 49, No. 12, pp. 1306-1311, 2016.

[51] Ruiz-Benitez, R., López, C., and Real, J., "Environmental Benefits of Lean, Green and Resilient Supply Chain Management: The Case of the Aerospace Sector", Journal of Cleaner Production, Vol. 167, pp. 850-862, 2017.

[52] F. Ciccullo, M. Pero, M. Caridi, J. Gosling, and L. Purvis, "Integrating The
Environmental and Social Sustainability Pillars into The Lean and Agile Supply Chain Management Paradigms: A Literature Review and Future Research Directions", Journal of Cleaner Production, Vol. 172, No. 20, pp. 2336-2350, 2017.

[53] Salvador, R., Piekarski, C., and Francisco, A., "Approach of The Two-Way Influence Between Lean and Green Manufacturing and Its Connection to Related Organizational Areas", International Journal of Production Management and Engineering, Vol. 5, No. 2, pp. 73-83,2017.

[54] Cherrafi, A., Elfezazi, S., Govindan, K., Garza-Reyes, J., Benhida, K., and Mokhlis, A., "A Framework for The Integration of Green and Lean Six Sigma for Superior Sustainability Performance", International Journal of Production Research, Vol. 55, No. 15, pp. 4481-4515, 2017.

[55] Azfar, K., Shahzad, N., and Mumtaz, S., "Application of Lean Agile Resilient Green Paradigm Framework on China Pakistan Economic Corridor: A Case Study", Mehran University Research Journal of Engineering and Technology, Vol. 36, No. 3, pp. 621-634, Jamshoro, Pakistan, July, 2017.

[56] Chowdhury, P., Tornatore, M., Sarkar, S., and Mukherjee, B., "Building A Green WirelessOptical Broadband Access Network (WOBAN)", Journal of Lightwave Technology, Vol. 28, No. 16, pp. 2219-2229, 2010.

[57] Wang, B., Wu, Y., Han, F., Yang, Y.-H., and Liu, K., "Green Wireless Communications: A Time-Reversal Paradigm", IEEE Journal On Selected Areas in Communications, Vol. 29, No. 8, pp. 1698-1710, 2011.

[58] Bu, S., Yu, F., Cai, Y., and Liu, X., "When The Smart Grid Meets Energy-Efficient Communications: Green Wireless Cellular Networks Powered by The Smart Grid", IEEE Transactions on Wireless Communications, Vol. 11, No. 8, pp. 30143024, 2012.

[59] Suarez, L., Nuaymi, L., and Bonnin, J.-M., "An Overview and Classification of Research Approaches in Green Wireless Networks", 
Eurasip Journal On Wireless

*Communications and Networking, Vol. 2012, No. 1, p. 142, 2012.

[60] Mahapatra, R., Domenico, A., Gupta, R., and Strinati, E., "Green Framework for Future Heterogeneous Wireless Networks", Computer Networks, Vol. 57, No. 6, pp. 1518-1528, 2013.

[61] Abou-Zeid, H., and Hassanein, H., "Predictive Green Wireless Access: Exploiting Mobility and Application Information", IEEE Wireless Communications, Vol. 20, No. 5, pp. 92-99, 2013.

[62] De Domenico, A., Strinati, E., and Capone, A., "Enabling Green Cellular Networks: A Survey and Outlook", Computer Communications, Vol. 37, pp. 5-24, 2014.

[63] Olesen, P., Powell, D., HVolumeby, H.-H., and Fraser, K., "Using Lean Principles to
Drive Operational Improvements in Intermodal Container Facilities: A Conceptual Framework", Journal of Facilities Management, Vol. 13, No. 3, pp. 266-281, 2015.

[64] M. Z. Rafique, "A Framework for RFID Technology Combined Lean Implementation in Automotive Parts Manufacturing Industry", $\mathrm{PhD}$ Thesis, Mechanical Engineering Department, UKM, Bangi, 2017.

[65] Gandotra, P., and Jha, R., "A Survey On Green Communication and Security Challenges in 5G Wireless Communication Networks", Journal of Network and Computer Applications, Vol. 96, pp. 39-61, 2017.

[66] Wang, B., Yang, Q., Yang L., and. Zhu, C., "On Minimizing Energy Consumption Cost in Green Heterogeneous Wireless Networks", Computer Networks, Vol. 129, pp. 522-535, 2017.

[67] Dahal, M., Shrestha, J., and Shakya, S., "Energy Saving In Green Wireless Communication By Dynamic Transmitter Shutdown Technique", Energy, Vol. 159, pp. 21-31, 2018. 